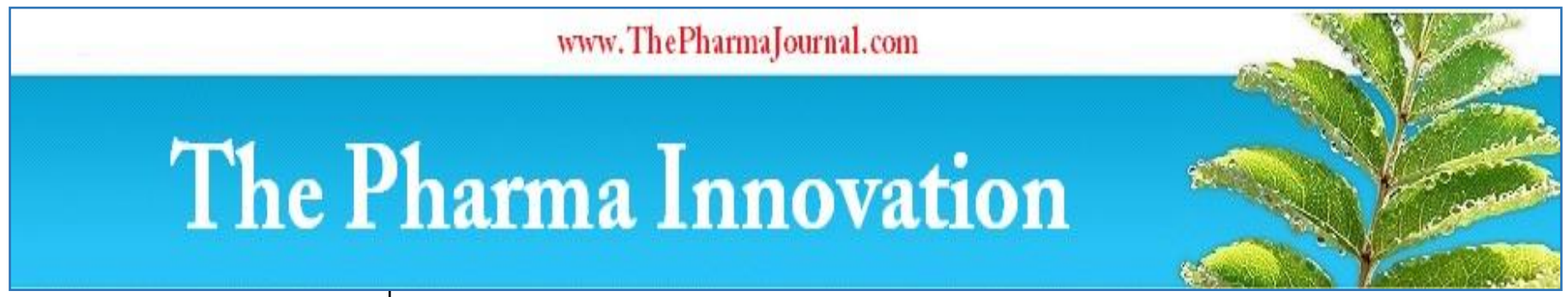

ISSN (E): 2277 - 7695

ISSN (P): 2349-8242

NAAS Rating: $\mathbf{5 . 0 3}$

TPI 2020; 9(7): 114-116

(C) 2020 TPI

www.thepharmajournal.com

Received: 10-05-2020

Accepted: 12-06-2020

Suryapal Singh

Guest Faculty, Shri Vishaw

Karma Skill University, Dudhola

Palwal, Haryana, India

Harshita Singh

PhD Scholar Department of

Vegetable Science, CCSHAU

Hisar, Haryana, India
Corresponding Author:

Suryapal Singh

Guest Faculty, Shri Vishaw

Karma Skill University, Dudhola

Palwal, Haryana, India

\section{Generic information on fennel to combat cough and cold in COVID19 era}

\section{Suryapal Singh and Harshita Singh}

DOI: https://doi.org/10.22271/tpi.2020.v9.i7b.4843

\section{Abstract}

Today there are a plenty of reasons why we kind of dread the nip in the air and the most important is COVID19 fear. Virus is playing havoc to the extent that almost all the activities are put to halt. The fear is to this extent that even simple cold and cough threatened us to be victim of COVID19. Symptoms are confusing and needs to be differentiated. In want of knowledge of differential diagnosis accurately pin pointing of disease is difficult without undergoing technology based tests. There are a lot of herbs and spices that you can use to boost your immunities. Fennel is renowned to soothe cold and cough. Fennel seeds, or saunf, are often found in mouth fresheners, beverages like fennel water (an excellent detox beverage), ladoos and even gravies. But the herb and its medicinal properties have been part of Ayurvedic treatment since time immemorial. The aromatic herb is used to soothe digestion, bloating, cramps and flatulence. They are also helpful in maintaining hormonal balance ie interior milieu. Fennel seeds are also packed with a range of anti-inflammatory volatile oils and antioxidants that can help keep risk of cold, cough and flu at bay. According to the book 'Healing Foods' by DK Publishing House, syrup made from the juice of fennel seeds are traditionally used to thin mucus. The seeds are also a good source of vitamin C, which fights free radical activity and keep one's immune system strong against seasonal infections. Fennel seeds and their phytonutrients are also effective in clearing sinus and chest congestion. Here we will discuss this traditional knowledge for the benefit of community.

Keywords: Generic information COVID19 era, fennel tea

\section{Introduction}

Unlike differential diagnosis, systems of medicine are so integrated that one medical practitioner is found to practice mixed approach and this is very common with Ayurveda. However, there are many modes which need to be differentiated, take the case of conventional and traditional methods of medicine. Complementary medicine is treatments that are used along with standard medical treatments but are not considered to be standard treatments. To cite is using acupuncture to help lessen some side effects of cancer treatment. Alternative medicine is treatments that are used instead of standard medical treatments. Herbal medicines are one type of dietary supplement. They are prepared as tablets, capsules, powders, teas, extracts, and fresh or dried plants. People use herbal medicines to try to maintain or improve their health. Many people believe that products labeled "natural" are always safe and good for them Herbs and spice seeds have all those virtues based on our traditional knowledge. Cough and cold are commonly occurring ailments and almost every one encounters it. Though these infections and diseases are seasonal, treating them with strong medicines can often lead to several other health issues such as nausea, bloating or diarrhea are a few to name. No wonder the best way to deal with such seasonal ailments is by going for some homemade remedies, which not only cure the common cold and flu, but at the same time strengthens immunity and prevents from such allergies and infections

India Covers a large area and happens to be the largest exporter of fennel seeds, widely known as saunf. Taking fennel seeds as mouth freshner after every meal is a common practice of Indian consumers. This not only freshen the mouth, but a rich source of minerals like Copper, Potassium, Calcium, Zinc, Manganese, Vitamin C, Iron, Selenium and Magnesium etc. This traditional practice does much more than simply beat bad breath. From regulating blood pressure to water retention, fennel seeds pack a bevy of nutrients that make it a must have in your kitchen. We have found an amazing natural remedy -- Fennel (saunf) tea, which has become a fad among people for its miraculous health benefits to treat cough and cold in this COVID19 era where common cough and cold is confused and illogically ill diagnosed. 


\section{Material and methods}

Information available on net was searched for use of traditional use of fennel in treating different disease but specific to cold and cough. The data was analysed and presented for the use and benefit of the people in this era of COVID19 where it is difficult to different common cold symptoms and COVID19 symptomatically. Since ages fennel has been used as home remedy for various ailments. Right from being a wonderful detoxifying herb, fennel works effectively in treating digestive issues such as stomach ache, bloating, cramps, flatulence and hormonal imbalance. Even in Ayurveda, fennel has been one of the major ingredients used to prepare Ayurvedic medicines. Fennel tea is a perfect remedy for cold, cough and flu as it is enriched with the goodness of antioxidants and vitamin $\mathrm{C}$, which naturally combats infections and seasonal cold. Moreover, fennel seeds are also loaded with anti-inflammatory volatile oils and phytonutrients, which helps in preventing as well as cutting sinus congestion and cold.

\section{How to make fennel tea}

According to experts, eating fennel seeds after meal boosts metabolism and helps in bile production, which further helps in proper digestion as well as bowel movement. Fennel seeds can be a part of your meal from raw to treated. Take one cup water and boil one teaspoon fennel seeds and allow it steep for some time. To accentuate the taste of this tea, add some green tea leaves and one teaspoon honey and delve in the goodness of this healthy herbal tea for use in cough and cold showing flu like symptoms confused with COVID19 symptoms. Proximate analysis of fennel seeds by different workers was analysed and correlated about their health benefits on different physiological functions in the body.

\section{Result and discussion}

Oil content of the seed varied from 10.7 to $19.0 \%$. The amount of petroselinic acid present as C18 monoenes was found by ozonization of the mixed methyl esters, reduction to aldehydes, and consequent GLC analysis; the amount ranged from $70-75 \%$ of the oil and was not significantly affected by either agronomy practices. GC and GC-MS analysis of the fennel essential oil revealed the presence of 23 compounds, with major components like Trans anethol (69.87\%), fenchone (10.23\%), estragole $(5.45 \%)$ and limonene $(5.10 \%)$.The fennel seed extracts contained appreciable levels of total phenolic contents (627.21-967.50 GAE, mg/100 g) and total flavonoid contents (374.88-681.96 CE, mg/100 g). Fennel essential oil and extracts also exhibited good DPPH radical scavenging activity, showing IC50 32.32 and 23.61$26.75 \mu \mathrm{g} / \mathrm{ml}$, and inhibition of per oxidation 45.05 and 48.80 $70.35 \%$, respectively (Moreau et al, 1966) ${ }^{[7]}$. Of the fennel essential oil and solvent extracts tested, $80 \%$ ethanol extract exhibited the maximum. Proximate and mineral analysis of fennel seeds is quantitative determination of a mixture to find the percentage of components. This analysis gives a true picture of chemical contents of fennel seeds. Proximate composition showed that fennel seed contains moisture, crude protein, crude fat, crude fiber, ash and NFE as $6.23 \pm 0.24$, $9.29 \pm 0.36, \quad 9.67 \pm 0.28, \quad 18.14 \pm 0.67, \quad 13.00 \pm 0.48$ and $44.02 \pm 0.92 \%$, respectively. Likewise mineral profiling in showed high potassium $848.54 \pm 32.25 \mathrm{mg} / 100 \mathrm{~g}$ followed by calcium $585.06 \pm 25.36 \mathrm{mg} / 100 \mathrm{~g}$, manganese $210.37 \pm 6.40$ $\mathrm{mg} / 100 \mathrm{~g}$, sodium $15.98 . \pm 0.58 \mathrm{mg} / 100 \mathrm{~g}$ and iron $10.06 \pm 0.48$ $\mathrm{mg} / 100 \mathrm{~g}$ whereas zinc was found only in traceable quantities.
Proximate analysis is a measure to estimate the relative amounts of moisture, protein, lipid, fiber, ash and carbohydrate. Protein, lipid and carbohydrate each contribute to the total energy content while water and ash only contribute mass. These reports are in consonance with investigations of Saeed et al. (2009) ${ }^{[10]}$. They reported that percentage of moisture, protein, fat and fiber in fennel was 8.05 \pm 1.35 , $1.21 \pm 0.06, \quad 0.18 \pm 0.12$ and $2.97 \pm 0.4 \%$, respectively. Furthermore, Kaur and Arora, (2010) ${ }^{[5]}$ reported that fennel seed contains moisture $8.39 \%$, ash $9.8 \%$, fiber $14.80 \%$ and protein $15.68 \%$ on dry basis. Faten et al. (2011) ${ }^{[4]}$ found the chemical composition of fennel and observed that fennel contains $23.19 \%$ crude protein, $17.51 \%$ fiber, $10.50 \%$ ash, $9.96 \%$ fat and $7.27 \%$ moisture, correspondingly. The data regarding proximate composition in current studies is in consonance with previous findings of Anubhuti et al. (2011) [1]; Rather et al. (2012) ${ }^{[9]}$ and Chittora \& Veer (2013) ${ }^{[3]}$ who reported from different laboratories and concluded that moisture; protein, fat, ash, fiber and NFE contents of fennel are $6.3,9.5,10,13.4,18.5$ and $42.3 \%$, respectively on dry basis. Minerals are crucial and inevitable part of diet as they constitute only 4-6\% of human body. Mineral analysis related results of fennel seeds were verified by findings of Ozcan et al. (2008) ${ }^{[8]}$ who worked on mineral contents of some medicinal plants which are mostly used as traditional condiments. Level of $\mathrm{K}$ of fennel seed in this work was found to be very higher than those of others. Mineral content of fennel Seed was 2019.2, 1030.1, 11.6, 4.52, 3.81 and 1.54 $\mathrm{mg} / 100 \mathrm{~g}$ for potassium, calcium, iron, sodium, manganese and zinc. Importance of these elements and their antioxidant activity cannot be overemphasized because different enzymes require them as a cofactor. Koudela and Petříková (2008) ${ }^{[6]}$ suggested the monitored parameters of potassium, sodium, manganese and calcium in fennel as 504.6, 29.45, 23.55 and $20.95 \mathrm{mg} / 100 \mathrm{~g}$ and trace amount of iron and zinc. Sodium, potassium and calcium are the major micronutrients present in plants as an essential cations. These minerals are required for human body in large amounts. However, their deficiency results in arthritis bone and tooth related disorders. Manganese is an important element for proper and normal growth of human bone structure. It is a very significant mineral in aiding to increase mineral density of spinal bone. Fe is required for production of red blood cells in a process known as the haematopoiesis, but it is also part of hemoglobin (pigment of RBC) that binds to oxygen to facilitate its transport from the lungs via the arteries to all cells throughout the body. Zinc is required for working of insulin, fertility as well as for mental and body growth. Improvement in above physiological parameters due to constituents of fennel seeds and their extract in fennel tea (vernicularly called Kada) is reported to relieve cough and cold symotons.

\section{Conclusions}

Traditional knowledge and ITK's are commonly used in remote areas where sophisticated medical facilities are not available and people find it difficult to reach these places in want of conveyance. This knowledge of Ayuerveda is of great use and help relieve the patients. Ayurveda was in advance stage in our country and we are considered as world Guru in it. In present situation when COVID19 is playing havoc and everyone is in fear this traditional knowledge is helping them to ease out of cough and cold symptoms by consuming fennel tea (commonly called Kada). 


\section{References}

1. Anubhuti P, Rahul S, Kant KC. Standardization of Fennel (Foeniculum vulgare), Its oleoresin and marketed ayurvedic dosage forms. Int. J. Pharma. Sci and Drug Res. 2011; 3(3):265-269.

2. book 'Healing Foods' by DK Publishing House, 2013.

3. Chittora M, Veer C. Biology and biotechnology of fennel. Int. J. Bioassays. 2013; 2(12):1616-1619.

4. Faten AE, Farag M, Hanan AK. Chemical analysis of fennel seeds, basil leaves and their essential oil contents. J. Biol. Chem. Environ. Sci. 2011; 6(2):127-145.

5. Kaur GJ, Arora DS. Bioactive potential of Anethum graveolens, Foeniculum vulgare and Trachyspermum ammi belonging to the family Umbelliferae: Current status. 2010; 4:87-94.

6. Koudela M, Petrŕková K. Nutritional compositions and yield of sweet fennel cultivars Foeniculum vulgare Mill. ssp. Vulgare var. azoricum (Mill.) Thell. Hort. Sci. 2008; 35(1):1-6.

7. Moreau JP, Holmes RL, Ward TL et al. Evaluation of yield and chemical composition of fennel seed from different planting dates and row-spacings. J Am Oil Chem Soc. 1966; 43:352-354.

8. Ozcan MM, Unver A, Uçar T, Arslan D. Mineral content of some herbs and herbal teas by infusion and decoction. Food Chem. 2008; 106:1120-1127.

9. Rather MA, Dar BA, Sofi SN, Bhat BA, Qurishi MA. Foeniculum vulgare: A comprehensive review of its traditional use, phytochemistry, pharmacology, and safety. Arabian J. Chem. 2012; 1:1-10.

10. Saeed MK, Ejaz N, Ahmed I, Ashraf M, Haq IU, Iqbal I et al. Nutritional evaluation and DPPH assay of Pakistani variety of fennel (Foeniculum vulgare). Comp Med Eng. 2009; 1:1-4. 